\title{
Atmospheric emissions of volatile organic compounds from a mine soil treated with sewage sludge and tomato plants (Lycopersicum esculentum L.)
}

\author{
Antonio José Fernández-Espinosa ( $\nabla$ anjose@us.es ) \\ Universidad de Sevilla https://orcid.org/0000-0001-5690-1463 \\ Aranzazu Peña-Heras \\ IACT: Instituto Andaluz de Ciencias de la Tierra \\ Sabina Rossini-Oliva \\ Universidad de Sevilla Facultad de Biologia
}

\section{Research Article}

Keywords: Phytoremediation, mine soil, volatile organic compounds (VOCs), emissions, BTEX, TVOCs

Posted Date: March 7th, 2022

DOI: https://doi.org/10.21203/rs.3.rs-1068434/v2

License: (c) (1) This work is licensed under a Creative Commons Attribution 4.0 International License.

Read Full License 


\section{Abstract}

Aims. The study investigated the emissions of volatile organic compounds (VOCs) from a mining soil amended with sewage sludge and irrigated with wastewater with or without tomato plants. The aim is to find out whether amendment and irrigation change VOC emissions from the soil and whether tomato changes emissions compared to uncultivated soil.

Methods. Soil and plant experiments were done in assembled pots. All pots were placed inside a closed glass chamber inside an isolated and windowless room. Experiments with soil without plants were done independently from experiments with soil and plants. An aspirating pump coupled with Tenax adsorbent tubes was used for sampling of VOCs emitted from pots. Volatile organic compounds trapped in the tubes were quantified by gas chromatography-mass spectrometry detection.

Results. The study detected a total of nine VOCs emitted from the polluted soil: benzene, toluene, ethylbenzene, $p$-xylene, $m$-xylene, $o$-xylene, styrene, benzene-1,2,4-trimethyl and tetrachloroethylene, among which the most abundant were toluene, $m$-xylene and styrene. Differences between pots with or without amendments ( $\mathrm{C}$ and $\mathrm{A}$ pots) showed a general tendency to a decline of VOCs emissions in the mining soil amended with sewage sludge. Plants contributed to increase significantly the emissions of all VOCs in both A and C-pots.

Conclusion. The soil amended with sewage sludge reduced the emission of VOCs: styrene in pots without plants and benzene and xylenes in pots with plants. Tomato plants contributed to increase significantly the emissions of all VOCs except styrene in both amended and non-amended soils.

\section{Introduction}

Volatile organic compounds (VOCs) are emitted from soils during decomposition or transformation of soil organic matter (OM) (Insam, 2013). Some studies state that soil can emit VOCs to the atmosphere although they are often 1-2 orders of magnitude lower than those from aboveground vegetation, thus, soil acts as both a source and sink for VOCs (Peñuelas et al., 2014). In soils, VOCs are produced by all living organisms (Leff \& Fierer, 2008) such as microbes or worms, and by no living components, including dissolved OM, particulate OM pools (Mc Bride et al., 2020) and landfill wastes (Randazzo et al., 2020).

The patterns of VOC emission by a soil can change depending on soil conditions, including nutrient availability (Levesque et al., 2018), soil fertilization (Raza et al., 2017; Potard et al., 2017; Giagnoni et al., 2020), soil microbial abundance and composition (Trowbridge et al., 2020) or soil pollution (Franco et al., 2014; Faubert et al., 2017). VOCs are emitted into the atmosphere in large quantities from a variety of different natural (Guenther, 2013) and anthropogenic sources (Qiu et al., 2014). Regarding natural compounds, Giagnoni et al. (2020) reported a shift from the production of acetate towards the production of acetone and acetaldehyde after liming the soil and an increase in methanol release as a consequence of tillage. A paddy soil amended with biochar and rice straw led to a reduction in $\mathrm{CH}_{4}$ emission, but did not affect $\mathrm{CO}_{2}$ release (Kumputa et al., 2019). Similarly, a horticultural medium amended with different 
types of biochars reduced the emission of $\mathrm{CO}_{2}, \mathrm{CH}_{4}$ and $\mathrm{N}_{2} \mathrm{O}$ (Levesque et al., 2018), while addition of paper mill sludge to a mine tailing resulted in an increased $\mathrm{CO}_{2}$ emission but negligible release of $\mathrm{CH}_{4}$ (Faubert el al., 2017). In addition, yard waste compost produced emissions of volatile compounds as a result of biological breakdown (Büyüksönmez and Evans, 2007). Therefore, the addition of organic matter to the soil leads to an increase or a reduction of gas emissions in the atmosphere, depending on the type of amendment.

Regarding anthropogenic compounds, the main VOCs studied in soils amended with sewage sludge are benzene, toluene, ethylbenzene, xylenes and styrene (Urionabarrenetxea et al., 2021). The emission reduction of VOCs after addition of biochar has been attributed to increased adsorption of VOCs by the soil, like benzene, toluene, ethylbenzene, and xylenes (BTEXs) (Vikrant et al., 2020). This adsorption is highly dependent on biochar nature and on the physicochemical properties of the volatiles, being lower for benzene and higher for the rest of non-polar and hydrophobic compounds (Saiz-Rubio et al., 2019). BTEXs, are the hydrocarbons of utmost concern in contamination events, because of their greater solubility in water and mobility in soils, being also enlisted among the top 100 priority pollutants by the US-EPA (Feng et al., 2021). Usually, when metal-contaminated soils are amended with sewage sludge or irrigated with wastewater, they receive volatile organic aromatic compounds of the BTEXs type from these inputs (Feng et al., 2021). In petroleum contaminated soils, BTEXs and PAHs are usually used as toxic indicators to assess their hazardousness (Niu and Lin, 2021). The highly mutagenic and carcinogenic effects of BTEXs require effective remediation (Akmirza et al. 2017).

Reclaiming contaminated soil through plants is a practice that intends to improve the quality of both the soil and the plant cover, which may mitigate the harmful effects of pollutants, by reducing their mobility and bioavailability or by improving their degradation (Nejad et al., 2017; Wyszkowska et al., 2019; Xie and Van Zyl, 2020: Rai et al., 2021). Furthermore, the use of industrial or urban organic wastes as soil conditioners is considered one of the most effective and inexpensive operations to improve biochemical properties of soils contaminated by trace metals (Burgos et al., 2010; Asemaninejad et al., 2021).

Therefore, knowing whether the application of both ameliorating strategies produces an increase of VOCs emissions to the atmosphere is essential in order to avoid possible environmental problems in the future. Although VOCs emission from soil amended with organic waste products has been previously studied (Seewald et al., 2010; Abis et al., 2018), literature on VOC emission from soil/vegetation of mining areas is scarce (Faubert et al., 2017, Giagnoni et al., 2020).

The aim of this study was the assessment of VOCs emission from a mining soil irrigated with wastewater, a) without amendments, b) amended with sewage sludge and c) planted with tomato plants (Lycopersicum esculentum L.). We studied whether amendment and irrigation change the VOCs emission by the soil and if tomato causes changes with respect to emissions from the only-soil. This species is a good option as food and is commonly cultivated in soil in almost any country, either developed or under development, precisely by its worldwide extension (FAO, 2021).

\section{Materials And Methods}


Soil samples were collected in the mining dump of Riotinto mining area (Nerva, province of Huelva, Spain). It is located in the Iberian Pyrite Belt $\left(37^{\circ} 42^{\prime} 4.5^{\prime \prime} \mathrm{N}-6^{\circ} 33^{\prime} 35.1^{\prime \prime} \mathrm{W}\right)$, the largest deposit of pyrite $\left(\mathrm{FeS}_{2}\right)$ and other metallic and polymetallic sulfides (Chopin and Alloway, 2007). Random subsamples to a depth of $20 \mathrm{~cm}$ from the site were composited into a bulk soil sample. The composite soil sample was homogenized in the laboratory with a cement mixer, air dried for 2 weeks and sieved through a 8-mm mesh for pot assays or through 2-mm mesh and ground to $50 \mu \mathrm{m}$ for analysis following standard methodologies.

The soil was characterized as sandy-loam and, according to X-ray fluorescence analysis, $\mathrm{SiO}_{2}(46.9 \%)$, $\mathrm{Fe}_{2} \mathrm{O}_{3}(23.0 \%)$ and $\mathrm{Al}_{2} \mathrm{O}_{3}(12.7 \%)$ represent more than $80 \%$ of the soil mineralogical composition (Mingorance et al., 2014). It is very acidic ( $\mathrm{pHH}_{2} \mathrm{O} 2.4$ ) with low organic carbon content (OC $\left.1.4 \%\right)$, and high electrical conductivity (EC $1.3 \mathrm{dS} \mathrm{m}^{-1}$, at 1:2.5 ratio), 24\% water content at field capacity, humification index (HIX) 1.16 and specific UV absorbance $10.8 \mathrm{~L} \mathrm{~g}^{-1} \mathrm{~cm}^{-1}$. Soil ionic content $\left(\mathrm{mg} \mathrm{kg}^{-1}\right)$ is $\mathrm{Na}^{+} 26.1 \pm 0.2, \mathrm{NH}_{4}{ }^{+} 4.45 \pm 0.07, \mathrm{~K}^{+} 26 \pm 5, \mathrm{Ca}^{2+} 118 \pm 17, \mathrm{Mg}^{2+} 25 \pm 2, \mathrm{Cl}^{-} 4.90 \pm 0.13, \mathrm{NO}_{2}^{-} 0.180 \pm$ $0.005, \mathrm{NO}_{3}{ }^{-} 65.1 \pm 0.6, \mathrm{PO}_{4}{ }^{3-} 0.42 \pm 0.03$ and $\mathrm{SO}_{4}{ }^{2-} 1334 \pm 65$ (Peña et al., 2015). The soil content of some potential hazardous elements (As, 3951; $\mathrm{Cd}, 13 ; \mathrm{Cu}, 694 ; \mathrm{Pb}, 3976$, all in $\mathrm{mg} \mathrm{kg}^{-1}$ ) was above the regional guidelines for agricultural soils (Aguilar et al., 1999).

Stabilized sewage sludge (SSL), obtained from the wastewater treatment plant (WTP) of 'Carrión de los Céspedes' (Sevilla, SW Spain), was used as amendment of the mining soil (MS). The main properties of SSL were: neutral pH $6.90 \pm 0.01, \mathrm{HIX} 0.43$, EC (at 1:10 ratio, w/v) $2.8 \pm 1.2 \mathrm{dS} \mathrm{m}^{-1}$ and high organic carbon (OC) content (\%) $35.50 \pm 2.94$. Humic acid content was $1.6 \%$ and fulvic acid content $0.47 \%$. The potential toxic metal load of SSL at the $2 \%$ dose used $\left(40-80 \mathrm{Mg} \mathrm{ha}^{-1}\right)$ was lower than that corresponding to European guidelines concerning external application to soil (European Commission, 1986). Ionic content ( $\left.\mathrm{mg} \mathrm{kg}^{-1}\right)$ was higher than the soil: $\mathrm{Na}^{+} 55 \pm 11, \mathrm{NH}_{4}{ }^{+} 551 \pm 29, \mathrm{~K}^{+} 20.7 \pm 0.6, \mathrm{Ca}^{2+}$ $1222 \pm 28, \mathrm{Mg}^{2+} 40 \pm 8, \mathrm{Cl}^{-} 86.7 \pm 0.4, \mathrm{NO}_{2}{ }^{-} 2.128 \pm 0.002, \mathrm{NO}_{3}{ }^{-} 8.0 \pm 0.4, \mathrm{PO}_{4}{ }^{3-} 0.53 \pm 0.06$ and $\mathrm{SO}_{4}{ }^{2-}$ $3317 \pm 184$ (Peña et al., 2015). SSL was sieved through a 2-mm mesh.

Irrigation was performed with wastewater (wW) from the same WTP, whose main properties were: $\mathrm{pH} 8.7$ \pm 0.3 and EC $1.063 \pm 0.088 \mathrm{dS} \mathrm{m}^{-1}$ and high OC content.

Pot assembling, treatments and experiments

Prior to pot assembling, the original MS was limed with Carbocal ${ }^{\circledR}\left(C A_{L}\right)$, a liming amendment proceeding from the Azucarera Iberia, a sugar Spanish company. It is based on a sugar factory subproduct, rich in calcium carbonate (83.4\%) and with an OC content of $5.1 \%$ (at an equivalent rate of $1.5 \%$ $w / w)$. This calcium carbonate $-0.75 \mathrm{~g} \mathrm{~kg}^{-1}$ - raises soil to $\mathrm{pH} 7.3$, obtaining a limed soil $\left(\mathrm{MS}_{\mathrm{L}}\right)$. 
All pots were placed inside a closed glass chamber of 90 litres, which was located in an isolated, windowless room during 5 days. Experiments with soil without plants were done separately from experiments with plants (Fig. 1a-b). In the glass chamber, indoor relative humidity and level of $\mathrm{CO}_{2}$ was increasing continuously during the incubation, mainly in pots with plants. After five days of incubation, volatile compounds emitted by each pot were collected by aspirating the air inside a conical glass hood, which covered completely the pots (Fig. 1C). The indoor air was aspirated by a suction pump located outside the chamber, which channelled it to an adsorbent tube where the VOCs were trapped.

Prior to the pot experiments, VOCs blanks were initially determined for each type of substance solid/liquid- added to soil:

- Ultrapure water (uW, reference of blanks)

- the original mining soil (MS)

- the liming product $\left(\mathrm{CA}_{L}\right)$

- the stabilized sewage sludge (SSL)

- the wastewater for irrigation (wW)

Glass Petri dishes were used as supports of these substances. An equal equivalent amount of each of the solid/liquid substances was added to each Petri dish $(10 \mathrm{~g}$ or $10 \mathrm{~mL})$, which was then aspirated through the conical glass hood into the adsorbent tube (Fig. 1d).

Pot experiments were prepared per triplicate for two different treatments, constituting a set of six pots (Fig.s 1a-b): Control treatment (C) and amendment treatment (A). C-pots were prepared mixing the mining soil (250 g MS), glassy beads (40 g, 15\% $w / w)$ and liming amendment $\left(5 \mathrm{~g}, 2 \% w / w C A_{\llcorner}\right)$, giving a limed soil $\left(\mathrm{MS}_{\mathrm{L}}\right)$. A-pots were prepared adding stabilized sewage sludge $(2 \% w / w S S L)$ to $\mathrm{MS}_{\mathrm{L}}$, giving an amended soil $\left(\mathrm{MS}_{\mathrm{SL}}\right)$.

Two experiments were designed. The first pot experiment was done using C-pots and A-pots without plants ( $-P$, Fig. 1a) and the second one was carried out using $C$-pots and A-pots planted with tomato plants $(+P$, Fig. 1 b). Prior to sampling, prepared pots were irrigated with wastewater $(45 \mathrm{~mL}, 80 \%$ field capacity), thus stabilizing them to reach a pH close to 7 , at which the soil microbiota is activated. At this point, VOC emissions from the soil were sampled from each of the six pots (three C-pots and three Apots).

Transplanted plants were previously grown into a standard vegetal substrate until their size was high enough for transplanting them into the MS. One individual was transplanted in each pot. After 5 days, VOC emissions were sampled.

VOCs sampling 
Sampling of VOCs was performed using an aspirating pump coupled with adsorbent tubes. Glass tubes were manually assembled and conditioned. Each glass adsorbent tube (Perkin-Elmer) was filled with 60 mg of Tenax® TA 60/80 (Perkin-Elmer), which is the most commonly sorbent used (Jansen et al., 2008; Balao et al., 2011). The sorbent was fixed to the centre of the tube with glass wool and stainless steel springs at both ends. Then filled tubes were conditioned before sampling by oven heating at $250^{\circ} \mathrm{C}$ for 2 hours and quick nitrogen assisted cooling inside a desiccator. While awaiting sampling, the tubes were kept capped at both openings.

Blanks and added compounds were aspirated towards the adsorbent tube using an air sampling pump (Casella, Apex model) with the following conditions: air flow $1.6 \mathrm{~mL} \mathrm{~min}^{-1}$, air volume 72 litres (45 min), temperature and relative humidity $22.4 \pm 0.2^{\circ} \mathrm{C}$ and $38.9 \pm 0.6 \%$, respectively, and $\mathrm{CO}_{2}$ rate $634 \pm 33 \mathrm{ppm}$. After sampling, each tube was immediately capped and stored in the freezer $\left(-22^{\circ} \mathrm{C}\right)$ until chromatographic analysis.

VOC analysis

Volatile organic compounds in the air were quantified by gas chromatography-mass spectrometry detection (GC-MSD). VOCs trapped inside the tubes were desorbed and led to the chromatograph (Bruker 450-GC) using an automatic thermal desorption injector (Turbomatrix ATD 350, Perkin Elmer). Volatiles were desorbed using a thermal desorption program: $250^{\circ} \mathrm{C}$ for $5 \mathrm{~min}$ at $30 \mathrm{~mL} \mathrm{~min}{ }^{-1}$ of helium with a cold trap at $5^{\circ} \mathrm{C}$, and then heating the cold trap to $250^{\circ} \mathrm{C}$ at $20^{\circ} \mathrm{C} \mathrm{min}^{-1}$. The VOCs were channelled to the chromatographic column ( $30 \mathrm{~m}$ length $\times 0.25 \mathrm{~mm}$ internal diameter $\times 0.25 \mu \mathrm{m}$ film thickness). The oven temperature program for the separation of VOCs inside the DB-5 Agilent J\&W column was: initial temperature of $40^{\circ} \mathrm{C}$ for $3 \mathrm{~min}, 10^{\circ} \mathrm{C} \mathrm{min}^{-1}$ to $120^{\circ} \mathrm{C}$ and $25^{\circ} \mathrm{C} \mathrm{min}{ }^{-1}$ to $250^{\circ} \mathrm{C}$. Helium, the thermal

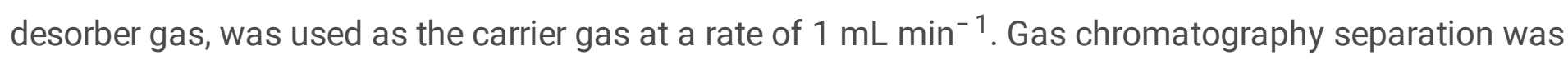
coupled with a quadrupole mass spectrometer (Bruker 300-MS). Detection of VOCs were carried out at full-scan mode (Q1 and Q3), for a mass range from 30 to $450 \mathrm{~m} / \mathrm{z}$ and by electronic impact ionization. The identification was by comparison with the NIST spectral library (National Institute of Standards and Technology, Gaithersburg, MD, USA). The data obtained were collected using the Bruker software Chemical Analysis MS Workstation version 7.0 (Karlsruhe, Germany).

VOC-Mix 20 standard was used for the analytical calibration of the VOCs detected. The chromatographic signal of each VOC was relativized to the four internal standards pentafluoro-benzene, 1,4-difluorobenzene, chloro-benzene-d5, 1,4-dichloro-benzene-d4 of the Mix 11-IS standard (both Mix standard were purchased from Dr. Ehrenstorfer). Calibration curves were prepared in volumetric flasks at the range $0.25-35 \mathrm{ng} \mathrm{hL}^{-1}(\mathrm{ppm})$. Afterwards, $10 \mu \mathrm{L}$ of each diluted standard were added with a microsyringe into each glass adsorbent tube and then a continuous flow of nitrogen was passed through the tube. All tubes were handled inside a vertical laminar flow cabinet (equipped with an activated carbon filter). Each peak was identified by the absolute and the relative retention times, and by comparison with the mass spectral library of the instrument. Final concentrations in the air were expressed as $\mathrm{gg} \mathrm{m}^{-3}$. 


\section{Statistical analysis}

Normality was tested by Shapiro-Wilk's test and the homogeneity of variance was established with the Levene's test $(p>0.05)$. One-way analysis of variance (ANOVA) was performed followed by a post-hoc test (LSD) to analyse differences of VOC emissions between pot experiments. When data were nonnormally distributed non-parametric tests were applied (Kruskal-Wallis and Mann-Whitney U-test). Data analyses were performed using StatSoft (Version 8).

\section{Results}

Nine volatile organic compounds were studied: benzene, toluene, $m$-xylene, $p$-xylene, $o$-xylene, ethylbenzene, styrene, tetrachloroethylene and benzene-1,2,4-trimethyl. The nine different VOCs identified represent the volatile compounds with the highest analytical signal obtained in the GC-MS (Table 1 and Fig. 2). The original mining soil was limed with $C A_{L}$, amended with $S S L$ and irrigated with $w W$. Before studying which VOC comes from the plant or from the soil it is essential to investigate if $C A_{L}, S S L$ or wW emit volatile compounds on their own. Results on VOCs emitted by the different substances are shown in Table 2, showing the contribution of each one to the total VOC emitted in each pot. Thus, we know their potential relative contribution at the start of the experiment (first day), prior to sampling after 5 days of incubation. As Table 2 shows, MS (45\%) and wW (52\%) would be the main contributors, with negligible contribution from $\mathrm{CA}_{\mathrm{L}}(0.2 \%)$ or ultrapure water and low supply from SSL (3\%, except for benzene).

Benzene was also found in a limed degraded soil (Giagnoni et al., 2020). The differences should be due to their different physical and chemical characteristics and to the different microorganisms present in these materials (Hocinat et al., 2017). 
Table 1

Some physical-chemical properties of the VOCs determined by GC-MSD, $\mathrm{K}_{\mathrm{ow}}$, octanol/water partition coefficient

\begin{tabular}{|c|c|c|c|c|c|c|}
\hline Compound & $\begin{array}{l}\text { Chemical } \\
\text { formula }\end{array}$ & $\begin{array}{l}\text { Molecular } \\
\text { weight (g } \\
\mathrm{mol}^{-1} \text { ) }\end{array}$ & $\begin{array}{l}\text { Retention } \\
\text { time* } \\
\text { (min) }\end{array}$ & $\begin{array}{l}\text { Vapor } \\
\text { pressure* } \\
(\mathrm{kPa} 20 \\
\left.{ }^{\circ} \mathrm{C}\right)\end{array}$ & $\begin{array}{l}\text { Solubility in } \\
\text { water }^{* *}\left(\mathrm{mg} \mathrm{L}^{-}\right. \\
\text {1) }\end{array}$ & $\begin{array}{l}\log \\
\mathrm{K}_{\mathrm{ow}}\end{array}$ \\
\hline Benzene & $\mathrm{C}_{6} \mathrm{H}_{6}$ & 78.11 & 4.44 & 10.0 & 1790 & 2.13 \\
\hline Toluene & $\mathrm{C}_{7} \mathrm{H}_{8}$ & 92.14 & 6.46 & 2.9 & 526 & 2.73 \\
\hline Ethylbenzene & $\mathrm{C}_{8} \mathrm{H}_{10}$ & 106.17 & 8.87 & 0.9 & 170 & 3.15 \\
\hline$p$-xylene & $\mathrm{C}_{8} \mathrm{H}_{10}$ & 106.17 & 9.10 & 0.9 & 160 & 3.20 \\
\hline$m$-xylene & $\mathrm{C}_{8} \mathrm{H}_{10}$ & 106.17 & 10.62 & 0.8 & 180 & 3.12 \\
\hline o-xylene & $\mathrm{C}_{8} \mathrm{H}_{10}$ & 106.17 & 9.30 & 0.7 & 165 & 3.15 \\
\hline $\begin{array}{l}\text { Benzene 1,2,4- } \\
\text { trimethyl }\end{array}$ & $\mathrm{C}_{9} \mathrm{H}_{12}$ & 120.19 & 13.66 & - & 300 & 2.95 \\
\hline Styrene & $\mathrm{C}_{8} \mathrm{H}_{8}$ & 104.15 & 12.93 & 0.3 & 206 & 3.40 \\
\hline Tetrachloroethylene & $\mathrm{C}_{2} \mathrm{Cl}_{4}$ & 165.83 & 6.00 & 1.9 & 57 & 3.63 \\
\hline \multicolumn{7}{|c|}{ *: Retention time in the GC-MSD chromatogram } \\
\hline **: data from the $\mathrm{Ha}$ & oook of $\mathrm{C}$ & stry and $\mathrm{F}$ & cs (Lide & & & \\
\hline
\end{tabular}


Table 2

Contribution of volatile compounds emitted by the pots components in $\mu \mathrm{g} \mathrm{m}^{-3}$ (\% for the mean and sum).

\begin{tabular}{|c|c|c|c|c|c|c|}
\hline & $u W *$ & MS & $\mathrm{CA}_{\mathrm{L}}$ & SSL & wW & mean (\%) \\
\hline \multicolumn{7}{|c|}{ Equivalent volatile emissions by pot $\left(10 \mathrm{~g} \mathrm{MS}+2 \% \mathrm{CA}_{\mathrm{L}}+2 \% \mathrm{SSL}+\mathrm{wW}\right)$} \\
\hline Benzene & n.d. & 0.287 & n.d. & 0.020 & 0.127 & $0.145(39)$ \\
\hline Toluene & n.d. & n.d. & n.d. & 0.001 & 0.062 & $0.032(8)$ \\
\hline Ethylbenzene & n.d. & 0.118 & n.d. & 0.002 & 0.053 & $0.058(15)$ \\
\hline$p$-xylene & n.d. & n.d. & n.d. & 0.004 & 0.094 & $0.049(13)$ \\
\hline$m$-xylene & n.d. & 0.035 & 0.0010 & 0.001 & 0.029 & $0.017(4)$ \\
\hline o-xylene & n.d. & n.d. & n.d. & 0.002 & 0.071 & $0.037(10)$ \\
\hline Benzene-1,2,4-trimethyl & n.d. & 0.017 & 0.0002 & 0.001 & 0.058 & $0.019(5)$ \\
\hline Styrene & n.d. & n.d. & 0.0003 & n.d. & 0.015 & $0.008(2)$ \\
\hline Tetrachloroethylene & n.d. & n.d. & n.d. & 0.001 & 0.022 & $0.012(3)$ \\
\hline sum (TVOCs, \%) & $0(0)$ & $0.457(45)$ & $0.0015(0.2)$ & $0.030(3)$ & $0.531(52)$ & \\
\hline
\end{tabular}

The mine soil showed an initial level of VOC similar $\left(0.46 \mu \mathrm{g} \mathrm{m}^{-3}\right)$ to that of $w W\left(0.53 \mu \mathrm{g} \mathrm{m}^{-3}\right)$; however, it should be noted that pots were irrigated with wW every day, so the wW relative contribution is expected to be higher at the moment of sampling (10th day). Besides, different volatile compounds have been reported in WTPs, being aromatic hydrocarbons and organosulphur compounds the most abundant chemical classes (Gomez-Rico et al., 2008; Jiang et al., 2017; Byliński et al., 2019). This would explain the relative high contribution of $\mathrm{wW}$, taking into account their corresponding inputs to the pot experiment.

\section{Discussion}

Table 3 shows the relative proportion of the emitted volatiles in pot experiments. The first remarkable result was the high concentration of toluene emitted by pots in all experiments (abundance $77.4 \%$ $86.2 \%$ of TVOCs), followed by $m$-xylene $(2.8 \%-5.6 \%)$ and styrene $(1.2-5.1 \%)$. The less representative VOC emitted $(0.42 \%-0.55 \%)$ was benzene-1,2,4-trimethyl. While in the composition of original pots (Table 2), the potential contribution was higher for benzene (39\%) than for toluene (8\%), benzene emission only reached $2.8 \%-3.4 \%$. This decrease in the emitted VOCs also happened with the other studied VOCs (except $m$-xylene and styrene), in comparison with the initial pot conditions (at the first day). Toluene was presumably originated from the initially most concentrated compound in the pots, i.e., benzene. In addition, according to Table 2, the major source of toluene was wW, whose contribution 
would increase until sampling, because the pots were incubated for 5 days. The emission of VOCs from a soil depends on oxygen availability and on the physiological status of the microorganisms (Insam and Seewald, 2010). Besides, soil mineral composition is also another important factor that has an action on VOCs adsorption while emissions of VOCs are strongly related to the substrate quality (Abis et al., 2018).

Table 3

Relative percentage of total VOCs emitted in the pot experiments. Control pots $(C)$ and amended pots $(A)$ with $(+P)$ and without $(-P)$ tomato plants.

\begin{tabular}{|c|c|c|c|c|c|}
\hline $\begin{array}{l}\text { Volatile compound } \\
\text { (\%) }\end{array}$ & $\begin{array}{l}\text { C-Pots/MS } \mathrm{M}^{-} \\
\mathrm{P}\end{array}$ & $\begin{array}{l}\text { A-Pots/MS } \text { SSL }^{-} \\
\text {P }\end{array}$ & $\begin{array}{l}\text { C- } \\
\text { Pots } / \mathrm{MS}_{\mathrm{L}}+\mathrm{P}\end{array}$ & $\begin{array}{l}\text { A- } \\
\text { Pots/MS }\end{array}$ & mean \\
\hline Benzene & 2.8 & 3.2 & 3.4 & 2.9 & 3.1 \\
\hline Toluene & 77.4 & 79.8 & 85.4 & 86.2 & 82.2 \\
\hline Ethylbenzene & 1.4 & 1.1 & 1.4 & 1.4 & 1.3 \\
\hline$p$-xylene & 2.4 & 1.9 & 2.2 & 1.5 & 2.0 \\
\hline$m$-xylene & 5.1 & 5.6 & 2.8 & 2.9 & 4.1 \\
\hline o-xylene & 1.6 & 1.4 & 1.6 & 1.1 & 1.4 \\
\hline $\begin{array}{l}\text { Benzene-1,2,4- } \\
\text { trimethyl }\end{array}$ & 0.6 & 0.5 & 0.4 & 0.4 & 0.5 \\
\hline Styrene & 5.1 & 3.8 & 1.2 & 1.9 & 3.0 \\
\hline Tetrachloroethylene & 3.6 & 2.7 & 1.6 & 1.7 & 2.4 \\
\hline$\Sigma$ BTXs (\%) & 89.3 & 91.9 & 95.4 & 94.6 & 92.8 \\
\hline ¿BTEXs (\%) & 90.7 & 93.0 & 96.8 & 95.9 & 94.1 \\
\hline$\Sigma$ TVOCs (\%) & 100.0 & 100.0 & 100.0 & 100.0 & 100.0 \\
\hline \multicolumn{6}{|c|}{$\begin{array}{l}\text { C-Pots } / \mathrm{MS}_{\mathrm{L}}-\mathrm{P} \text {, mining soil without amendment and without plants; } \mathrm{A}-\mathrm{Pots} / \mathrm{MS}_{\mathrm{SL}}-\mathrm{P} \text {, mining soil with } \\
\text { amendment and without plants; } \mathrm{C}-\mathrm{Pots} / \mathrm{MS}_{\mathrm{L}}+\mathrm{P} \text {, mining soil without amendment and with plants; } \mathrm{A}- \\
\text { Pots } / \mathrm{MS}_{\mathrm{SL}_{\mathrm{L}}}+\mathrm{P} \text {, mining soil with amendment and plants }\end{array}$} \\
\hline
\end{tabular}

Benzene was mainly emitted by MS, wW and SSL (Table 2). Other authors corroborated that catechol, benzoate, phenol and toluene are the usual metabolites of benzene degradation (Oka et al., 2008). Ulrich et al. (2005) demonstrated that benzene was converted to toluene by benzene methylation and to phenol by benzene hydroxylation under anaerobic conditions. Under the current work conditions, the glass chamber was closed during 5 days, resulting in a continuous increase of $\mathrm{CO}_{2}$ level. Furthermore, $\mathrm{MS}$ and SSL have a high concentration of ions favoring anaerobic conditions $\left(3300-4000 \mathrm{mg} \mathrm{kg}^{-1} \mathrm{SO}_{4}{ }^{=}, 551-\right.$ $1410 \mathrm{mg} \mathrm{kg}^{-1} \mathrm{NH}_{4}{ }^{+}$, only $8-18 \mathrm{mg} \mathrm{kg}^{-1} \mathrm{NO}_{3}{ }^{-}$, Peña et al., 2015). Therefore, it is to be expected that the 
increased anoxic conditions during incubation would have favored the mechanism of benzene degradation by sulfate-reducing bacteria, allowing the formation of toluene by methylation. Similar processes may have occurred for ethylbenzene, $p$, $o$-xylenes and benzene-1,2,4-trimethyl. For instance, Pseudomonas putida has an initial degradation rates higher for $m$ - and $p$-xylene than for toluene (Duetz et al., 1998).

With regard to differences between pots with or without amendments ( $C$ and $A$ pots), a general tendency to a decline of VOCs emissions in the mining soil amended with sewage sludge was observed (Fig. 2). In pots without plants $(-P)$ this reduction was remarkable but only significant for styrene $(-34 \%, p<0.05)$ while for pots with plants $(+P)$ the reduction was significant for benzene, $p, m$, and $o$-xylene $(-46 \%)$ while for styrene a significant increase was observed $(+23 \%, p<0.05)$. The observed reduction was especially high for the more hydrophobic compounds (higher log $\mathrm{K}_{\mathrm{ow}}$ values) and could be ascribed to enhanced adsorption by sewage sludge, as previously reported for biochars (Saiz-Rubio et al., 2019; Vikrant et al., 2020).

The retention of VOCs in soils can be stimulated by the addition of activated carbon (Bonaglia et al., 2020), although it is more usual to add organic amendments to soils, such as sewage sludges or biochars. Based on the data from Table 3, the retention percentage of pollutants in the soil due to the presence of SSL for the overall concentrations of BTXs and BTEXs was only $-10 \%$, and was not significant, neither for TVOCs ( $p>0.05,-13 \%)$, due mainly to the low reduction rates of benzene and toluene. Although TVOCs, BTXs and BTEXs did not significantly differ among treatments (with or without amendments) without plants (Table 3), the decrease of VOCs emissions from pots with plant was higher in the presence of SSL (-22\%) than without SSL (-13\%) (Fig. 2).

Plants contributed to increase significantly the emissions of all VOCs in both A and C- pots, except for styrene. The most marked effects by the tomato plant were observed for both benzene and toluene ( $x 4$ times/C-pots, $x 3$ times/A-pots) and ethylbenzene (x3 times/C-pots, $x 4$ times/A-pots). The increases of emissions were also notable for $p$,o-xylenes ( $x 3$ times/C-pots, $x 2$ times/A-pots) and for benzene-1,2,4trimethyl ( $x 3$ times/C-pots, $x 3$ times/A-pots). The presence of plants in pots increased significantly BTXs and BTEXs, while TVOCs emissions increased 4 times for non-amended -pots and 3 times for amended pots (Table 3, Fig. 3).

The presence of plants would enhance VOCs emission because these compounds would be uptake and translocated to the aerial parts. Hydrophobicity and molecular weight may influence the translocation processes of organic molecules in plants (Wang et al., 2021; Li et al., 2021). Although it has been reported that neutral compounds with $\log \mathrm{K}_{\mathrm{ow}}$ between -1 and 5 are considered mobile in the transpiration stream (Briggs et al., 1982), according to Sicbaldi et al. (1997) the efficiency of translocation would be best achieved by compounds with log $\mathrm{K}_{\text {ow }}$ values ranging from 2 to 3 , decreasing for compounds of lower or higher polarity. Therefore, VOCs with these log $\mathrm{K}_{\mathrm{ow}}$ values, like benzene, toluene and ethylbenzene (Table 1), are the ones preferentially translocated by the tomato plant and released to the atmosphere. 
On the other hand, addition of sewage sludge to the soil would increase adsorption and reduce the bioavailability of organic compounds for plant uptake, because the uptake potential of a compound is mainly dependent on the available concentration in soil solution. Amendment addition enhances soil OC, which is the main controlling factor of the adsorption of BTEX and other neutral hydrophobic pollutants (Zytner et al., 1994; Takaki et al., 2014). For instance, an inhibition of greenhouse gas emissions, such as

$\mathrm{CO}_{2}, \mathrm{~N}_{2} \mathrm{O}$, methane or ammonia, after sewage sludge amendment has been reported (Awasthi et al., 2016; Pandiyan et al., 2021). Besides, addition of sewage sludge does not only modify the soil porous microstructure, which in turn promotes adsorption, but also provides the soil with a source of labile OM, boosting the activity of soil microbes, which contribute to degrade VOCs (Agegnehu et al., 2016, Awasthi et al., 2020).

In summary, for both amended and non-amended mining soil, the tomato causes a large increase in VOC emissions, which means both a positive aspect for soils remediation but also a negative aspect for air pollution. This agrees with Yi et al. (2013), who indicated that in agricultural fields VOC emissions are largely produced by the aboveground living crops.

\section{Conclusions}

The addition of sewage sludge to the mining soil reduces the emission of VOCs from the soil, which is of great importance in the fate of volatiles emission to the atmosphere. Nevertheless, the cultivation of tomato plants in soil further increases the VOCs emission, although addition of sewage sludge partially compensates this increase, which demonstrates that plants are a sink and a source of volatile compounds. On the other hand, repeated irrigation with wastewater (under the current conditions) constitutes a source of VOC emission similar to that of soil and much higher than sludge. Further studies should be carried out on the VOC emissions from different types of soils, soil amendments, soil irrigation solutions and plant species. The overall balance of the results indicates that mining soils emit hazardous VOCs into the atmosphere.

\section{Declarations}

\section{Acknowledgements}

Wastewater and sewage sludge were provided by Dr. Ramón Bouza Deaño from the Andalusian Public Foundation 'Centro de las Nuevas Tecnologías del Agua' (CENTA) of the Junta de Andalucia Government. Carbocal were supplied by Juan Castellano Márquez from the Azucarera Iberia Company.

\section{Availability of data and materials Not applicable}

Author contribution The project conceptualization and design were mainly performed by Aranzazu PeñaHeras. Material preparation, analysis and data collection were mainly performed by Antonio José Fernández-Espinosa. The investigation, review and editing of revised manuscript were performed by Antonio José Fernández-Espinosa, Sabina Rossini-Oliva and Aranzazu Peña-Heras. 
Funding This work was supported by Proyecto de Excelencia-Junta de Andalucía (P10-RNM5814), cofinanced by FEDER funds.

Ethics approval Not applicable

Consent to participate Not applicable

Consent for publication Not applicable

Conflict of interest The authors declare no competing interests.

\section{References}

Abis, L., Loubet, B., Ciuraru, R., Lafouge, F., Dequiedt, S., Houot, S., Maron, P-A., Bourgeteau-Sadet, S., 2018. Profiles of volatile organic compound emissions from soils amended with organic waste products. Sci. Total Environ. 636, 1333-1343 https://doi.org/10.1016/j.scitotenv.2018.04.232

Agegnehu, G., Bass, A.M., Nelson, P.N., Bird, M.I., 2016. Benefits of biochar, compost and biocharcompost for soil quality, maize yield and greenhouse gas emissions in a tropical agricultural soil. Sci. Total Environ. 543, 295-306 https://doi.org/10.1016/j.scitotenv.2015.11.054

Aguilar, J., Dorronsoro, C., Galán, E., Gómez Ariza, J.L., 1999. Los criterios y estándares para declarar un suelo como contaminado en Andalucía y la metodología y técnica de toma de muestras y análisis para su investigación, in Investigación y Desarrollo Medioambiental en Andalucía. Eds. OTR/-University of Sevilla, pp 61-64

Akmirza, I., Pascual, C., Carvajal, A., Pérez, R., Muñoz, R., Lebrero, R., 2017. Anoxic biodegradation of BTEX in a biotrickling filter. Sci. Total Environ. 587-588: 457-465

https://doi.org/10.1016/j.scitotenv.2017.02.130

Asemaninejad, A., Langley, S., Mackinnon, T. Spiers, G., Beckett, P., Mykytczuk, N., Basiliko, N., 2021. Blended municipal compost and biosolids materials for mine reclamation: Long-term field studies to explore metal mobility, soil fertility and microbial communities. Sci. Total Environ. 760, 143393 https://doi.org/10.1016/j.scitotenv.2020.143393

Awasthi, M.K., Wang, Q., Ren, X., Zhao, J., Huang, H., Awasthi, S.K., Lahori, A.H., Li, R., Zhou, L., Zhang, Z., 2016. Role of biochar amendment in mitigation of nitrogen loss and greenhouse gas emission during sewage sludge composting. Bioresour. Technol. 219, 270-280

https://doi.org/10.1016/j.biortech.2016.07.128

Awasthi, M.K., Duana, Y., Awasthia, S.K., Liua, T., Zhang, Z., 2020. Effect of biochar and bacterial inoculum additions on cow dung composting. Bioresour. Technol. 297, 122407 https://doi.org/10.1016/j.biortech.2019.122407 
Balao, F., Herrera, J., Talavera, S., Dötterl, S., 2011. Spatial and temporal patterns of floral scent emission in Dianthus inoxianus and electroantennographic responses of its hawkmoth pollinator. Phytochemistry 72, 601-609. https://doi.org/10.1016/j.phytochem.2011.02.001

Bonaglia, S., Broman, E., Brindefalk, B., Hedlund, E., Hjorth, T., Rolff, C., Nascimento, F.J.A., Udekwu, K., Gunnarsson, J.S., 2020. Activated carbon stimulates microbial diversity and PAH biodegradation under anaerobic conditions in oil-polluted sediments. Chemosphere 248, 126023 https://doi.org/10.1016/j.chemosphere.2020.126023

Briggs, G.G., Bromilow, R.H., Evans, A.A., 1982. Relationships between lipophilicity and root uptake and translocation of non-ionised chemicals by barley. Pestic. Sci. 13, 495-504 https://doi.org/10.1002/ps.2780130506

Burgos, P., Madejón, P., Cabrera, F., Madejón, E., 2010. By-products as amendment to improve biochemical properties of trace element contaminated soils: Effects in time. Int. Biodeter. Biodegr. 64, 481-488 https://doi.org/10.1016/j.ibiod.2010.05.009

Büyüksönmez, F., Evans, J., 2007. Biogenic emissions from green waste and comparison to the emissions resulting from composting part II: Volatile organic compounds (VOCs). Compost Sci. Util. 15, 191-199 https://doi.org/10.1080/1065657X.2007.10702332

Byliński, H., Gębicki, J., Namieśnik, J., 2019. Evaluation of health hazard due to emission of volatile organic compounds from various processing units of wastewater treatment plant. Int. J. Environ. Res. Public Health 16, 1712 https://doi.org/10.3390/ijerph16101712

Chopin, E.I.B., Alloway, B.J., 2007. Trace elements partitioning and soil particle characterisation around mining and smelting areas at Tharsis, Riotinto and Huelva, SW Spain. Sci. Total Environ. 373, 488-500 https://doi.org/10.1016/j.scitotenv.2006.11.037

Duetz, W.A., Wind, B., van Andel, J.G., Barnes, M.R., Williams, P.A., Rutgers, M., 1998. Biodegradation kinetics of toluene, $m$-xylene, $p$-xylene and their intermediates through the upper TOL pathway in Pseudomonas putida (pwWO). Microbiology 144, 1669-1675 https://doi.org/10.1099/00221287-144-61669

Feng, S., Gong, L., Zhang, Y., Tong, Y., Zhang, H., Zhu, D., Huang, X., Yang, H., 2021. Bioaugmentation potential evaluation of a bacterial consortium composed of isolated Pseudomonas and Rhodococcus for degrading benzene, toluene and styrene in sludge and sewage. Bioresour. Technol. 320, 124329 https://doi.org/10.1016/j.biortech.2020.124329

Food and Agriculture Organization. FAOSTAT Crops (April 25 $5^{\text {th }}, 2021$ ) http://www.fao.org/faostat/en/\#data/QC/ 
Faubert, P., Durocher, S., Bertrand, N., Ouimet, R., Rochette, P., Tremblay, P., Boucher, J.F., Villeneuve, C., 2017. Greenhouse gas emissions after application of landfilled paper mill sludge for land reclamation of a nonacidic mine tailings site. J. Environ. Qual. 46, 950-960 https://doi.org/10.2134/jeq2017.03.0119

Franco, M.G., Corrêa, S.M., Marques, M., Perez, D.V., 2014. Emission of volatile organic compounds and greenhouse gases from the anaerobic bioremediation of soils contaminated with diesel. Water Air Soil Pollut. 225, 1879 https://doi.org/10.1007/s11270-014-1879-z

Giagnoni, L., Taiti, C., León, P., Costa, C., Menesatti, P., Espejo, R., Gómez-Paccard, C., Hontoria, C., Vázquez, E., Benito, M., Mancuso, S., Renella, G., 2020. Volatile organic compound emission and biochemical properties of degraded Ultisols ameliorated by no tillage and liming. Pedosphere 30, 597-606 https://doi.org/10.1016/S1002-0160(20)60024-8

Gomez-Rico, M.F., Fullana, A., Font, R., 2008. Volatile organic compounds released from thermal drying of sewage sludge. WIT Trans. Ecol. Environ. 111, 425-433 http://dx.doi.org/10.2495/WP080411

Guenther, A., 2013. Biological and chemical diversity of biogenic volatile organic emissions into the atmosphere. ISRN Atmospheric Sciences ID 786290 http://dx.doi.org/10.1155/2013/786290

Hocinat, A., Boudemagh, A., Ali-Khodja, H., Medjemadj, M., 2020. Aerobic degradation of BTEX compounds by Streptomyces species isolated from activated sludge and agricultural soils. Arch. Microbiol. 202, 2481-2492 https://doi.org/10.1007/s00203-020-01970-4

Insam, H. 2013. Soil volatile organic compounds as tracers for microbial activities in soil. In, Nannipieri, P., Pietramellara, G., Renella, G. (eds.) Omics in Soil Science. Caister Academic Press, Norfolk. pp. 127-138

Insam, H., Seewald, M., 2010. Volatile organic compounds (VOCs) in soils. Biol. Fertil. Soils 46, 199-213 https://doi.org/10.1007/s00374-010-0442-3

Jansen, R.M.C., Hofstee, J.W., Wildt, J., Verstappen, F.W.A., Bouwmeester, H.J., Posthhumus, M.A., van Henten, E.J., 2008. Health monitoring of plants by their emitted volatiles: trichome damage and cell membrane damage are detectable at greenhouse scale. Ann. Appl. Biol. 154, 441-452 https://doi.org/10.1111/j.1744-7348.2008.00311.x

Jiang, G.M., Melder, D., Keller, J., Yuan, Z.G., 2017. Odor emissions from domestic wastewater: A review. Crit. Rev. Environ. Sci. Technol. 47, 1581-1611 https://doi.org/10.1080/10643389.2017.1386952

Kumputa, S., Vityakon, P., Saenjan, P., Lawongsa, P., 2019. Carbonaceous greenhouse gases and microbial abundance in paddy soil under combined biochar and rice straw amendment. Agronomy 9, 228 https://doi.org/10.3390/agronomy9050228

Leff, J.W., Fierer, N. 2008. Volatile organic compound (VOC) emissions from soil and litter samples. Soil Biology \& Biochemistry 40, 1629-1636 
Levesque, V., Rochette, P., Ziadi, N., Dorais, M., Antoun, $\mathrm{H}_{\text {., }}$ 2018. Mitigation of $\mathrm{CO}_{2}, \mathrm{CH}_{4}$ and $\mathrm{N}_{2} \mathrm{O}$ from a fertigated horticultural growing medium amended with biochars and a compost. Appl. Soil Ecol. 126, 129139 https://doi.org/10.1016/j.apsoil.2018.02.021

Lide, D.R. (Ed.), 1996. Handbook of Chemistry and Physics (77 th ed.), CRC Press Inc, Boca Raton, FI.

Mc Bride, S.G., Choudoir, M., Fierer, N., Strickland, M.S. (2020). Volatile organic compounds from leaf litter decomposition alter soil microbial communities and carbon dynamics. Ecology 101, e03130 https://doi.org/10.1002/ecy.3130

Miller, E.L., Nason, S.L., Karthikeyan, K.G., Pedersen, J.A., 2016. Root uptake of pharmaceuticals and personal care product ingredients. Environ. Sci. Technol. 50, 525-541

https://doi.org/10.1021/acs.est.5b01546

Mingorance, M.D., Rossini, S., Valdés, B., Pina Gata, F.J., Leidi, E.O., Guzmán, I., Peña, A., 2014. Stabilized municipal sewage sludge addition to improve properties of an acid mine soil for plant growth. J. Soils Sediments 14, 703-712 https://doi.org/10.1007/s11368-013-0743-x

Nejad, Z.D., Kim, J.W., Jung, M.C., 2017. Reclamation of arsenic contaminated soils around mining site using solidification/stabilization combined with revegetation. Geosci. J. 21, 385-396 https://doi.org/10.1007/s12303-016-0059-0

Niu, A., Lin, C., 2021. Managing soils of environmental significance: A critical review. J. Hazard. Mater. 417, 125990 https://doi.org/10.1016/j.jhazmat.2021.125990

Oka, A.R., Phelps, C.D., McGuinness, L.M., Mumford, A., Young, L.Y., Kerkhof, L.J., 2008. Identification of critical members in a sulfidogenic benzene-degrading consortium by DNA stable isotope probing. Appl. Environ. Microbiol. 74, 6476-6480 https://doi.org/10.1128/AEM.01082-08

Pandiyan, B., Mangottiri, V., Narayanan, N., 2021. Carbon transformations of biochar based cocomposting - A review. Mini-Rev. Org. Chem. 18, 1-14 https://doi.org/10.2174/1570193X17999200928221205)

Peña, A., Mingorance, M.D., Guzmán-Carrizosa, I., Fernández-Espinosa, A.J., 2015. Improving the mining soil quality for a vegetation cover after addition of sewage sludges: inorganic ions and low-molecularweight organic acids in the soil solution. J. Environ. Manage. 150, 216-225 https://doi.org/10.1016/j.jenvman.2014.11.016

Potard, K., Monard, C., Le Garrec, J.-L., Caudal, J.-P., Le Bris, N., 2017. Organic amendment practices as possible drivers of biogenic volatile organic compounds emitted by soils in agrosystems. Agric. Ecosyst. Environ. 250, 25-36 https://doi.org/10.1016/j.agee.2017.09.007 
Qiu, K., Yang, L., Lin, J., Wang, P., Yang, Y., Ye, D., Wang, L., 2014. Historical industrial emissions of nonmethane volatile organic compounds in China for the period of 1980-2010. Atmos. Environ. 86, 102-112 https://doi.org/10.1016/j.atmosenv.2013.12.026

Rai, G.K., Bhat, B.A., Mushtaq, M., Tariq, L., Rai, P.K., Basu, U., Dar, A.A., Islam, S.T., Dar, T.U.H., Bhat, J.A., 2021. Insights into decontamination of soils by phytoremediation: A detailed account on heavy metal toxicity and mitigation strategies. Physiol. Plantarum 173, 287-304 https://doi.org/10.1111/ppl.13433

Randazzo, A., Asensio-Ramos, M., Melián, G.V., Venturi S., Padrón, E., Hernández, P.A., Pérez, N.M., Tassi, F., 2020. Volatile organic compounds (VOCs) in solid waste landfill cover soil: Chemical and isotopic composition vs. degradation processes. Sci. Total Environ. 726, 138326 https://doi.org/10.1016/j.scitotenv.2020.138326

Raza, W., Mei, X.L., Wei, Z., Ling, N., Yuan, J., Wang, J.C., Huang. Q.W., Shen, Q.R., 2017. Profiling of soil volatile organic compounds after long-term application of inorganic, organic and organic-inorganic mixed fertilizers and their effect on plant growth. Sci. Total Environ. 607-608, 326-338 https://doi.org/10.1016/j.scitotenv.2017.07.023

Saiz-Rubio, R., Balseiro-Romero, M., Antelo, J., Díez, E., Fiol, S., Macías, F., 2019. Biochar as low-cost sorbent of volatile fuel organic compounds: potential application to water remediation. Environ. Sci. Pollut. Res. 26, 11605-11617 https://doi.org/10.1007/s11356-018-3798-9

Seewald, M.S.A., Singer, W., Knapp, B.A., Franke-Whittle, I.H., Hansel, A., Insam, H., 2010. Substrateinduced volatile organic compound emissions from compost-amended soils. Biol. Fertil. Soils 46, 371382 https://doi.org/10.1007/s00374-010-0445-0

Shenker, M., Harush, D., Ben-Ari, J., Chefetz, B., 2011. Uptake of carbamazepine by cucumber plants - A case study related to irrigation with reclaimed wastewater. Chemosphere 82, 905-910 https://doi.org/10.1016/j.chemosphere.2010.10.052

Sicbaldi, F., Sacchi, G.A., Trevisan, M., Del Re, A.A.M., 1997. Root uptake and xylem translocation of pesticides from different chemical classes. Pestic. Sci. 50, 111-119 https://doi.org/10.1002/(SICI)10969063(199706)50:2<111::AID-PS573>3.0.C0;2-3

Takaki, K., Wade, A.J., Collins, C.D., 2014. Assessment of plant uptake models used in exposure assessment tools for soils contaminated with organic pollutants. Environ. Sci. Technol. 48, 12073-12082 https://doi.org/10.1021/es501086x

Trowbridge, A.M., Stoy, P.C., Phillips, R.P., 2020. Soil biogenic volatile organic compound flux in a mixed hardwood forest: net uptake at warmer temperatures and the importance of mycorrhizal associations. J. Geophys. Res.-Biogeo. 125, e2019JG005479 https://doi.org/10.1029/2019JG005479 
Urionabarrenetxea, E., Garcia-Velasco, N., Anza, M., Artetxe, U., Lacalle, R., Garbisu, C., Becerril, T., Soto, M., 2021. Application of in situ bioremediation strategies in soils amended with sewage sludges. Sci. Total Environ. 766, 144099 https://doi.org/10.1016/j.scitotenv.2020.144099

Vikrant, K., Kim, K.H., Peng, W.X., Ge, S.B., Ok, Y.S., 2020. Adsorption performance of standard biochar materials against volatile organic compounds in air: A case study using benzene and methyl ethyl ketone. Chem. Eng. J. 387, 123943 https://doi.org/10.1016/j.cej.2019.123943

Xie, L.X., van Zyl, D., 2020. Distinguishing reclamation, revegetation and phytoremediation, and the importance of geochemical processes in the reclamation of sulfidic mine tailings: A review. Chemosphere 252, 126446 https://doi.org/10.1016/j.chemosphere.2020.126446

Yi, Z.G., Zheng, L.L., Wu, T., Wang, X.M., 2013. Contribution of aboveground plants, the rhizosphere and root-free-soils to total COS and DMS fluxes at three key growth stages in rice paddies. Agric. Ecosyst. Environ. 179, 11-17 https://doi.org/10.1016/j.agee.2013.07.005

Wang, F.Y., Li, X., Yu, S.M., He, S.H., Cao, D.T., Yao, S.J., Fang, H., Yu, Y.L., 2021. Chemical factors affecting uptake and translocation of six pesticides in soil by maize (Zea mays L.). J. Hazard. Mater. 405, 124269 https://doi.org/10.1016/j.jhazmat.2020.124269

Wyszkowska, J., Borowik, A., Kucharski, J., 2019. The resistance of Lolium perenne L. x hybridum, Poa pratensis, Festuca rubra, F. arundinacea, Phleum pratense and Dactylis glomerata to soil pollution by diesel oil and petroleum. Plant Soil Environ. 65, 307-312 https://doi.org/10.17221/42/2019-PSE

Zytner, R.G. (1994). Sorption of benzene, toluene, ethylbenzene and xylenes to various media. J. Hazard. Mater. 38, 113-126 https://doi.org/10.1016/0304-3894(94)00027-1

\section{Figures}

\section{Figure 1}

The pots with mining soil only, $-P(\mathrm{a})$ and with the mining soil+plant, $+P(\mathrm{~b})$ were incubated inside the closed glass chamber. VOCs sampling from pots and Petri dishes was done using the yellow pump coupled with one adsorbent glass tube (c) connected to a glass conical hood (d). 


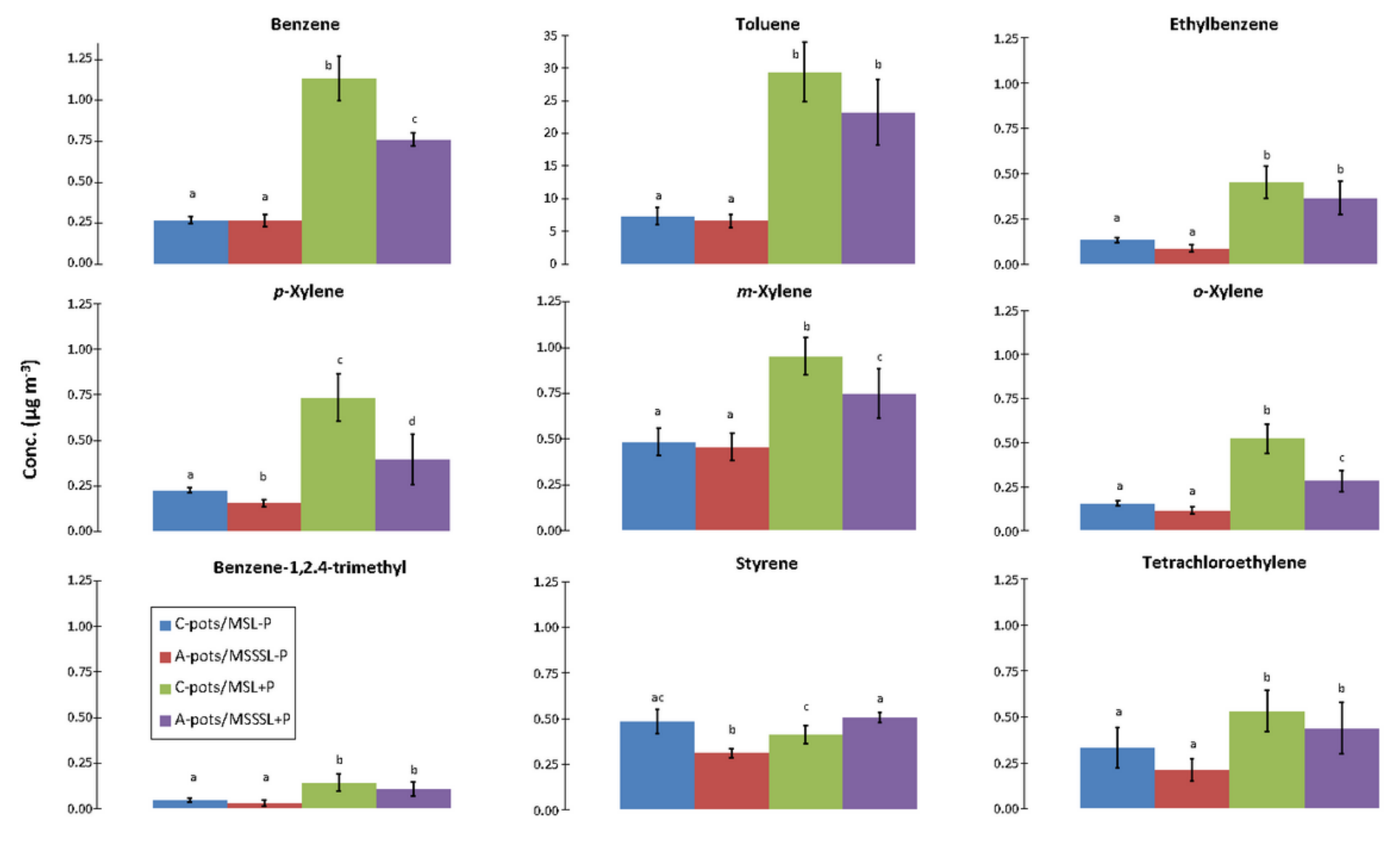

Figure 2

VOCs emitted in the experiment (mean \pm standard deviation, $n=3$ ). Different letters indicate significant differences $(p<0.05)$ between treatments. C-Pots/MSL-P, mining soil without amendment and without plants; A-Pots/MSSL-P, mining soil with amendment and without plants; C-Pots/MSL+P, mining soil without amendment and with plants; A-Pots/MSSL+P, mining soil with amendment and with plants 


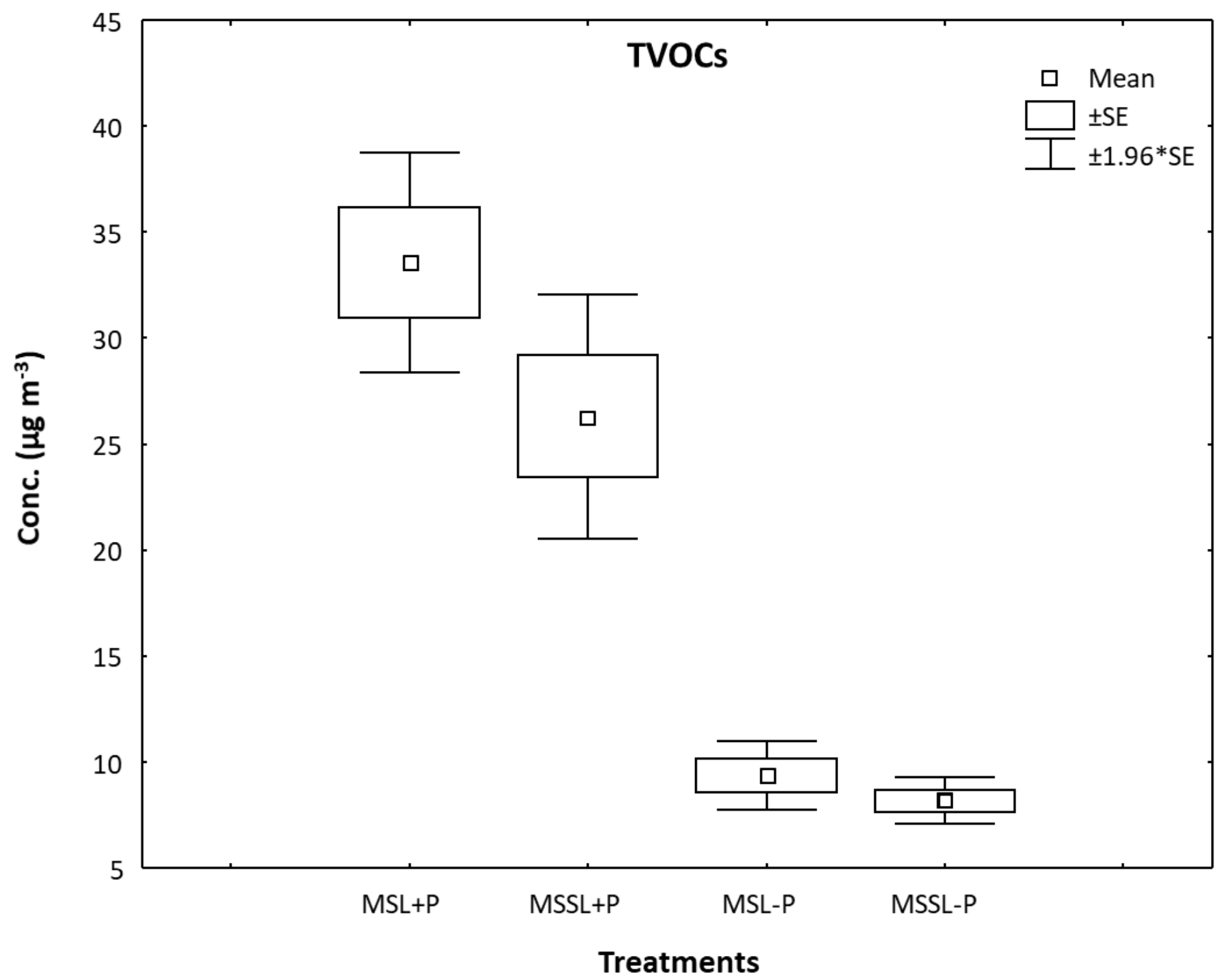

Figure 3

Total volatile compounds released in the different pot treatments. MSL+P, mining soil without amendment and with plants; MSSL $+P$, mining soil with amendment and with plants; $M S L-P$, mining soil without amendment and without plants; MSSL-P, mining soil with amendment and without plants. 